\section{Dypdykk i SS-strategien mot Norge}

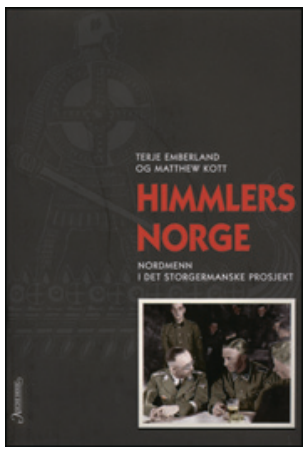

Terje Emberland, Matthew Kott Himmlers Norge

Nordmenn i det storgermanske prosjekt. 663 s, ill. Oslo: Aschehoug, 2012. Pris NOK 399 ISBN 978-82-03-29308-5

Himmlers Norge er resultatet av et forskningsarbeid som ble startet etter en mediedebatt i 2004. Var det mulig at norske Waffen-SSsoldater hadde deltatt i massakrer på østfronten i krigen mot SovjetRussland i årene 1941-45? Boken er skrevet av to historikere som har arbeidet med stoffet siden 2005, og begge er, eller har vært, tilknyttet Senter for studier av Holocaust og livssynsminoriteter.

Boken er omfangsrik og detaljert, men likevel lettlest og inndelt i relativt korte kapitler. Brødteksten ender på side 495, og på de neste 168 sidene finnes bl.a. noter og skjemaoversikter over den tyske SS-organisasjonen. Som det fremgår av tittelen, er Heinrich Himmler (1900-45), hans organisasjon og tankegods det sentrale. Himmler var en av Tysklands mektigste menn under den annen verdenskrig. En stor biografi om ham, skrevet av den tyske historikeren Peter Longerich, utkom i 2008.

Himmler ble født i München. Moren var troende katolikk, faren lærer. Den unge Heinrich var en svermer og ble et lett bytte for sosialdemokratene i 1920-årene. Etter at Adolf Hitler overtok partiet, ble Himmler tilhenger av Hitler og hans omdøpte Die Nationalsozialistische Deutsche Arbeiterpartei (NSDAP). Innenfor disse rammene startet han oppbyggingen av en livvakt rundt Hitler, Schutzstaffel (SS), mens Ernst Röhm (1887-1934) bygde opp Sturmabteilung (SA). SS vokste stadig i omfang. SA ble utslettet 30. juni 1934 i de lange knivers natt, og restene sluttet seg til SS. Da Hitler kom til makten i 1933, var SS en uniformert og bevæpnet hær som terroriserte gatene og angrep jøder, kommunister og medlemmer av andre partier enn Hitlers eget. Senere, etter 1942, ble Himmler med sitt Reichssicherheitshauptamt (RSHA) ansvarlig for millioners død, og han ble med rette kalt Hitlers bøddel.

Han var besatt av den ariske rase og av dannelsen av et Storgermania, der alle ariere skulle finne sin plass. Norge var et grunnfjell av ariere, mente han, og han besøkte landet to ganger våren 1941. Han inspiserte gamle gårder i Gudbrandsdalen, hørte norsk folkemusikk og besøkte vikingmuseene. Han forsøkte å organisere et norsk SS, men i tallmessig henseende ble dette en fiasko. Videre ble han motarbeidet, både skjult og åpent, av Josef Terboven (1898-1945) og av Vidkun Quislings (1887-1945) Nasjonal Samling (NS). Da krigslykken snudde i 1942-43, fikk han andre ting å tenke på enn sitt elskede Norge. Man kan vel trygt si at SS-Norge ble en fiasko. Men han fikk organisert bl.a. Divisjon Nordland, med mange norske feltsoldater som deltok i drap på Østfronten, og som ble blant de siste som forsvarte Hitler i Berlins gater i april-mai 1945. I boken finnes mange interessante detaljer og enkelthistorier, ikke minst om familien Johan B. Hjort (1895-1969) og NS, og historien rundt Bjørn Østring (1917-2012) og Svein Blindheim (f. 1916).

Boken er et godt stykke arbeid og vil være ypperlig lesestoff for historieinteresserte. Selv hadde jeg stort utbytte, men savnet en omtale av raseideologen Alfred Rosenberg (1893-1946).

\section{Godt skrevet om ledelse av helsetjenester}

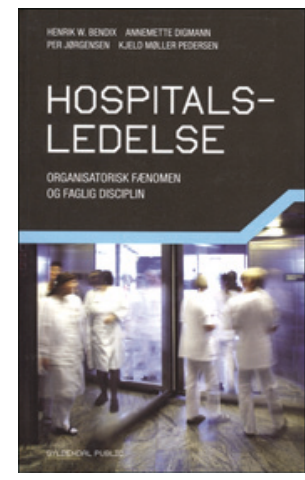

Henrik W. Bendix, Annemette Digmann,
Per Jørgensen, Kjeld Møller Pedersen

Hospitalsledelse

Oganisatorisk fænomen og faglig disciplin.

460 s, tab, ill.

København: Gyldendal Business, 2012.

Pris DKK 425

ISBN 978-87-02-12956-4

Jeg har lest en god bok. Fire rutinerte personer innen ledelse og helsetjenesteledelse av har satt sammen de viktigste problemstillingene omkring ledelse av helsetjenester. I 18 kapitler diskuterer forfatterne de aller fleste av de forhold som påvirker, preger og beskriver dette området. Det er tillegg et omfattende litteraturregister.

Her beskrives generell ledelse, organisatoriske prinsipper og styringsmekanikk. Ledelsesmodeller og organisatoriske løsninger diskuteres opp mot pasientforløp i et svært leseverdig kapittel, De nye ledelsesmodeller.

Et helt hovedkapittel i boken (kapittel 3: Ledelse af fagprofesioner) omhandler makt og maktspill i kompetanseorganisasjoner igjen meget leseverdig, gjenkjennbart. Styring av de fire «arketyper» av medarbeidere problematiseres - «primadonnaen», «prestasjonstripperen», «pragmatikeren» og «lønnsmottakeren».

Kapittel 8 og kapittel 9 omhandler det personlige lederskap og hvem som egentlig styrer. Her synes jeg forfatterne viser stor innsikt i hva helsetjenesteledelse innebærer og hvordan det foregår. Kapittel 9, Hvem bestemmer hva i hospitalet?, er meget velskrevet. Det er også et omfattende kapittel om ledelsesforskning om helsetjenesten.

Jeg vil avslutningsvis kommentere det siste kapitlet om fremtidens utfordringer i tjenesten og dermed ledelsen av den. Her beskrives gjenkjennbare scenarioer, utfordringsområder og mange mulige konflikter og dermed utfordringer - igjen meget leseverdig.

Etter mange år som leder i helsevesenet er det lenge siden jeg har lest noe som har vært så verdifullt for meg. Hospitalsledelse kan jeg anbefale på det varmeste til alle ledere og til dem som har tenkt å bli det.

Stener Kvinnsland

Helse Bergen 